\title{
DILEMATIS TENTANG PENDIDIKAN PEREMPUAN (KONSEP KESETARAAN GENDER)
}

\author{
Mahfud \\ Fakultas Ilmu Tarbiyah dan Keguruan \\ Institut Agama Islam Negeri Syekh Nurjati Cirebon \\ Email: mahfudsaid62@gmail.com
}

\begin{abstract}
ABSTRAK
Di Indonesia perjuangan perempuan untuk memperoleh keadilan dalam pendidikan, hingga saat ini masih terus menghadapi kendala. Akan ada beberapa faktor selama alur hidup seorang perempuan yang mempengaruhi perkembangan semangat dalam memperoleh pendidikan. Diantaranya, Sampai saat ini masih ada masyarakat yang berkeyakinan bahwa perempuan hanya akan berperan dalam ruang domestik saja yakni rumah tangganya kelak, yang kemudian hanya dipandang sebagai makhluk pelengkap saja. Sehingga meminggirkan perempuan untuk memperoleh pendidikan. Salah satu bentuk ketidakadilan untuk kaum perempuan adalah anggapan bahwa perempuan itu tidak penting, melainkan sekedar pelengkap dari kepentingan laki-laki, atau dikenal dengan istilah subordination. Dari pemahaman tersebut akhirnya perempuan dikonstruksikan agar tidak perlu sekolah tinggi-tinggi karena pada akhirmya akan kembali ke dapur juga. Bentuk ketidakadilan lain yakni pelabelan negatif yang dilekatkan kepada perempuan dikenal dengan istilah stereotype. Misalnya, perempuan yang melanjutkan sekolah hingga perguruan tinggi akan melakukan banyak kegiatankegiatan yang kurang bermanfaat untuk rumah tangganya kelak, apalagi ketika pendidikannya tinggi hampir seluruh laki-laki akan minder dan perempuan tersebut terancam menjadi perawan tua.Masyarakat juga masing ada yang berkeyakinan bahwa perempuan dengan fisik yang lebih lemah dan pasif, tidak memungkinkan mereka untuk dapat memenuhi mobilitas/aktvitas sebanyak dan sekuat laki-laki. Masyarakat berasumsi bahwa pendidikan hanya dapat dicapai oleh orang-orang yang mau bergerak dengan mobilitas tinggi, yang mau menghabiskan waktunya untuk membaca buku, melakukan eksperimen berjam-
\end{abstract}


jam di laboratorium, meneliti di lapangan, menulis dan berdiskusi dalam sisa waktunya, dan jika ini dilakukan oleh perempuan akan mengakibatkan mereka kehilangan identitas kewanitaannya karena tidak memiliki waktu untuk melakukan tugas-tugas kewanitaannya dirumah tangga dan keluarganya.

Kata Kunci: Pendidikan, Perempuan, Gender 


\section{A. Pendahuluan}

Pendidikan merupakan hak semua manusia. Laki-laki dan perempuan berhak memperoleh pendidikan dan mengabdikan ilmu yang telah diperolehnya untuk kebaikan umat manusia, baik dalam sektor domestik maupun publik. Sebagai bagian dari masyarakat yang diakui secara legal kewarganegaraannya, perempuan memiliki hak yang sama seperti warga negara lainnya, yakni mendapatkan pendidikan yang layak dan berkesinambungan. Hal ini tercermin dari beberapa Undang-undang Republik Indonesia dan beberapa Undang-undang Internasional yang sangat peduli pada hak-hak kaum perempuan, khususnya dalam bidang pendidikan.

Pemenuhan hak pendidikan juga sudah diatur dalam pasal 49 Undangundang No 35 Tahun 2014 tentang perubahan atas Undang-undang No.23Tahun 2002 tentang Perlindungan Anak bahwa Negara, pemerintahan, pemerintah daerah, keluarga, dan orang tua wajib memberikan kesempatan yang seluasluasnya kepada anak untuk memperoleh pendidikan. (Suryana, 2015: 15) ${ }^{1}$

Aturan dalam pasal tersebut sudah sangat jelas bahwa setiap orang berhak mendapatkan pendidikan. Semua orang berhak memanfaatkan ilmu pengetahuan dan teknologi dalam rangka meningkatkan kehidupan sosial yang lebih baik. Pemerintah harus melaksanakan isi ketentuan dalam pasal tersebut atas dasar nondiskriminasi. Selain itu dapat diketahui pula bahwa ada kewajiban dari pihakpihak yang disebut diatas untuk memberikan hak pendidikan kepada anak. Anak berhak mendapatkan kebebasan dalam memperoleh pendidikan. Pengekangan terhadap anak dalam rangka pemenuhan hak pendidikan merupakan bentuk pelanggaran hak asasi anak.

Undang-undang tersebut memberikan kepastian hukum bahwa setiap warga negara baik laki-laki dan perempuan berhak untuk mendapatkan pendidikan secara layak. Keharusan seorang perempuan menerima pendidikan tentu bukan tanpa alasan. Seperti yang diungkapkan Redja dalam bukunya "perempuan sebagai animal educandum perlu mendapatkan pendidikan agar mampu

\footnotetext{
${ }^{1}$ Yana Suryana. 2015. Gender dalam pendidikan. Yogyakarta : Cahaya Atma Pustaka, hal.15
} 
menyesuaikan diri dalam menghadapi lingkungan". (Redja Mudyaharjo.2013: $32)^{2}$

Yana Suryana (2015: 3$)^{3}$ menyatakan bahwa "Pada dasarnya kewajiban pemerintah sudah tercantum sebagaimana yang terdapat dalam alinea keempat Pembukaan Undang- Undang Dasar Negara Republik Indonesia Tahun 1945. Kewajiban Negara tersebut didasarkan pada tujuan negara yaitu mencerdaskan kehidupan bangsa". Kata "mencerdaskan kehidupan bangsa" merujuk pada usaha membangun manusia Indonesia yang mempunyai kualitas yang baik dan sumber daya yang unggul.

Guna mencapai tujuan tersebut, tentu perlu dilakukan upaya-upaya khusus. Diantaranya memberikan pendidikan yang baik. Pendidikan yang baik yaitu pendidikan yang nondiskriminasi. Kata nondiskriminasi memperlihatkan suatu pendidikan yang menyemaratakan seluruh peserta didik, baik perempuan maupun laki -laki.

Al Hadad yang di kutip oleh M. Roqib (2003:30) ${ }^{4}$ menyebutkan bahwa secara tradisional perempuan harus mendapatkan pendidikan yang memadai, sebab mereka niscaya akan menjadi pendidik, minimalnya bagi putra-putri yang mereka lahirkan, apalagi sebagai pendamping suami yang selalu membutuhkan pendidikan dan keterampilan yang memadai. Karena posisi strategis tersebut, perempuan perlu didukung dengan pendidikan yang kondusif, demokratis dan dinamis tanpa diskriminasi.

Kutipan di atas memberikan pandangan bahwa disetiap alur hidup seorang perempuan, sejak dia lahir sebagai seorang anak, tumbuh menjadi gadis muda kemudian menjadi seorang ibu hingga memasuki usia lanjut. Kesemua tahapnya itu perlu dibekali pengetahuan yang cukup. Terlebih saat menjadi seorang ibu. Posisi ini akan memerlukan pemenuhan pengetahuan dimana seorang ibu harus mampu menata kehidupannya secara pribadi dan tugas lain yakni memberikan kontribusi baik tenaga serta pikirannya untuk keluarga dan masyarakat.

Pada realitanya, perjuangan perempuan untuk memperoleh keadilan dalam pendidikan, khususnya di Indonesia hingga saat ini masih terus menghadapi

\footnotetext{
${ }^{2}$ Redja Mudyaharjo.2013. Pengantar Pendidikan. Jakarta: Rajawali Press, hal. 32

${ }^{3}$ Yana Suryana, Op. Cit, 2015, hal. 3

${ }^{4}$ Moh Roqib. 2003. Pendidikan perempuan. Yogyakarta: Gama media, hal. 30
} 
kendala. Akan ada beberapa faktor selama alur hidup seorang perempuan yang mempengaruhi perkembangan semangat dalam memperoleh pendidikan. Diantaranya, Sampai saat ini masih ada masyarakat yang berkeyakinan bahwa perempuan hanya akan berperan dalam ruang domestik saja yakni rumah tangganya kelak, yang kemudian hanya dipandang sebagai makhluk pelengkap saja. Sehingga meminggirkan perempuan untuk memperoleh pendidikan.

Musdah Mulia (2011: 67) ${ }^{5}$ menyebutkan salah satu bentuk ketidakadilan untuk kaum perempuan adalah anggapan bahwa perempuan itu tidak penting, melainkan sekedar pelengkap dari kepentingan laki-laki, atau dikenal dengan istilah subordination. Dari pemahaman tersebut akhirnya perempuan dikonstruksikan agar tidak perlu sekolah tinggi-tinggi karena pada akhirmya akan kembali ke dapur juga.

Bentuk ketidakadilan lain yakni pelabelan negatif yang dilekatkan kepada perempuan dikenal dengan istilah stereotype. Misalnya, perempuan yang melanjutkan sekolah hingga perguruan tinggi akan melakukan banyak kegiatankegiatan yang kurang bermanfaat untuk rumah tangganya kelak, apalagi ketika pendidikannya tinggi hampir seluruh laki-laki akan minder dan perempuan tersebut terancam menjadi perawan tua.

Menurut Eti Nurhayati (2012: 146) ${ }^{6}$ masyarakat juga masing ada yang berkeyakinan bahwa perempuan dengan fisik yang lebih lemah dan pasif, tidak memungkinkan mereka untuk dapat memenuhi mobilitas/aktvitas sebanyak dan sekuat laki-laki. Masyarakat berasumsi bahwa pendidikan hanya dapat dicapai oleh orang-orang yang mau bergerak dengan mobilitas tinggi, yang mau menghabiskan waktunya untuk membaca buku, melakukan eksperimen berjamjam di laboratorium, meneliti di lapangan, menulis dan berdiskusi dalam sisa waktunya, dan jika ini dilakukan oleh perempuan akan mengakibatkan mereka kehilangan identitas kewanitaannya karena tidak memiliki waktu untuk melakukan tugas-tugas kewanitaannya dirumah tangga dan keluarganya. Selain itu, fisik perempuan yang lemah yang digunakan untuk mobilitas pendidikan

\footnotetext{
${ }^{5}$ Musdah Mulia.2011. Muslimah Sejati. Bandung: Marja, hal. 67

${ }^{6}$ Eti Nurhayati. 2012. Psikologi Perempuan. Yogyakarta: Pustaka Pelajar, 146
} 
seperti laki-laki akan mengakibatkan perubahan fisik yang tidak menarik lagi bagi kaum laki-laki, dan ini merupakan penyimpangan bagi citra perempuan.

Anggapan-anggapan negatif kepada perempuan yang akhirnya menghegemoni masyarakat, khusunya masyarakat tradisional, dimana putri-putri mereka hanya diperbolehkan mengenyam pendidikan secukupnya saja, bukan hanya tidak memotivasi namun cenderung membatasi dan melarang dengan alasan - alasan yang dianggap sebagai bentuk kasih sayang, tetapi sesungguhnya memenjarakan dalam ketidakberdayaan.

Tidak hanya itu, dalam keluarga dengan latar belakang ekonomi yang rendah terkadang menjadi kendala untuk putri-putri mereka melanjutkan pendidikan. Misalnya, keluarga dari ekonomi menengah ke bawah, cenderung hanya menyekolahkan anak laki-laki mereka saja, karena laki-laki kelak akan menjadi seorang pemimpin, sedang perempuan disuruh membantu orang tuanya bekerja yang tidak lain sebagian besarnya juga turut membiayai pendidikan anak laki-lakinya tersebut.

Dilematis sekali ketika fenomena di setiap keluarga yang terbilang kurang mampu, ditambah pandangan hidup (way of life) yang masih demikian. Ketika memang kondisi ekonomi yang menjadi kendala, dan salah satu anak mereka harus membantu, tetaplah memotivasi mereka untuk semangat belajar sampai kapanpun. Bukan berarti tidak melanjutkan pendidikan dan hanya membantu orang tua itu suatu bentuk ketidakadilan. Sebaiknya orang tua menjelaskan secara bijak atas hak putra putri mereka sebagai seorang anak untuk memperoleh pendidikan, bukan kemudian membatasi akses pendidikan mereka karena melihat anak tersebut berjenis kelamin laki-laki dan perempuan.

Bukan hanya itu, dalam keluarga yang termasuk ekonomi menengah keatas sekalipun, kesempatan memperoleh pendidikan bagi perempuan masih terbatas, dikarenakan pandangan terhadap perempuan sebagai manusia yang utuh masih belum terbentuk sepenuhnya, apalagi jika harta yang kemudian akan diwariskan banyak, dianggaplah cukup perempuan itu memanfaatkan warisannya tersebut. Pada kenyataannya dalam mengelola harta atau hal apapun membutuhkan ilmu yang memadai agar tidak disia siakan begitu saja. Walaupun memang tidak semuanya demikian. 
Berkaitan dengan hal pandangan atau anggapan-anggapan tersebut dipengaruhi oleh beberapa hal diantaranya doktrin keagamaan, adat dan tradisi, hingga pada kesadaran manusianya itu sendiri. Dalam hal ini penulis mencoba menguraikan salah satu doktrin keagamaan yang sebenarnya perlu dikaji dan ditafsirkan ulang serta disesuaikan dengan perkembangan zaman.

Penulis yakin agama-agama di dunia ini khususnya Islam adalah agama yang ideal dan sangat sempurna. Ajarannya mencakup semua tuntutan luhur bagi kehidupan manusia dimuka bumi dalam semua bidang. Islam menjanjikan kebahagiaan hidup tanpa membeda-bedakan ras, suku bangsa, warna kulit, jenis kelamin dan gender: laki- laki dan perempuan. Permasalahannya hanya pada pemaknaan dan pemahaman pada teks teks agama, sebagai salah satu unsur dalam membentuk suatu kultur masyarakat.

Beberapa hadits yang lemah periwayatannya dan menghambat aktivitas pendidikan perempuan. Apabila hadis tersebut selalu ada kitab-kitab atau bukubuku kurikulum, tentu harus ditelaah ulang dengan pengetahuan yang memadai. Diantaranya adalah :

Beberapa teks hadis yang dikutip oleh Imam Ghazali (w.505H) dalam magnum opus nya Ihya 'Ulum ad-din dan Imam Nawawi (w.1315H) dalam kitab 'Uqud al Lujjain ketika berbiara mengenai kewajiban seorang istri. Beberapa juru dakwah agama saat ini, seperti dinyatakan oleh Syekh Muhammad Al Ghazali dalam kitan As-Sunah An Nabawiyyah, juga menjadikan teks hadis seperti ini sebagai dasar melarang perempuan memasuki jenjang pendidikan yang lebih tinggi (Zaitunah Subhan, 2008: 401-402). ${ }^{7}$

Walaupun memang dikutip oleh ulama yang terkenal, namun hadis tersebut tergolong hadis dhaif atau lemah dan tidak bisa dipertanggungjawabkan. Perlu dikaji ulang sebab-sebab mengapa Nabi mengatakan demikian (asbabul wurud), sebagaimana disebutkan oleh Haddad dan Al Ghazali bahwa teks seperti ini akan banyak menghambat perempuan untuk memperolehilmu pengetahuan dan pendidikan. Menurut beliau beberapa teks hadis seperti ini harus direnungkan, dikritik dan dimaknai ulang.

\footnotetext{
7 Zaitunah Subhan. 2008. Menggagas Fiqih Pemberdayaan Perempuan. Jakarta: El Kahfi, hal. 401-402
} 
Sama halnya dengan pemerintah, secara global pemerintah yang saat ini mengemban amanat rakyat dan tongkat kebijakan ada pada mereka. Namun pada kenyataannya beberapa persoalan diatas masih belum bisa teratasi dengan maksimal, masih banyak praktik-praktik pendidikan yang mendiskriminasikan kaum perempuan pada implementasinya.

Dengan banyaknya dasar-dasar mengenai hak pendidikan yang telah diungkapkan. Secara kuantitas dan kualitas, pendidikan perempuan masih perlu terus ditingkatkan, karena potensi, kesempatan, dan penghargaan yang sama untuk perempuan dan laki-laki merupakan keniscayaan untuk dapat bersinergi dalam kehidupan, bukan untuk saling mengkonter seperti yang selama ini dilabelkan kepada perempuan yang ingin maju. Bidang-bidang ilmu atau pekerjaan yang dianggap hanya pantas untuk laki-laki, perempuan harus juga mendapatkannya, karena yang membuat polarisasi pembidangan hanyalah konstruksi sosial kultural yang secara terus menerus dipertahankan. Perlu adanya formulasi-formulasi pendidikan yang adil atau nondiskriminasi.

\section{B. Konsep Pendidikan Perempuan}

Menurut Ahmadi yang dikutip Helmawati $(2014: 23)^{8}$ pendidikan atau paedagogie secara etimologi berasal dari bahasa Yunani, terdiri dari kata pais yang berarti anak dan again memiliki arti membimbing. Jadi pedagogie yaitu bimbingan yang diberikan kepada anak. Dalam bahasa Romawi, pendidikan diistilahkan dengan educate yang berarti mengeluarkan dari dalam.

Menurut RA Kartini yang dikutip oleh Soeroto $(2011: 363)^{9}$ pendidikan berarti membentuk watak dan akal pikiran. Tugas pendidik tidak berhenti pada pengembangan intelektual saja, dia wajib memelihara pembentukan wataknya. Karena perkembangan intelektual saja tidak menjamin nilai kesusilaannya.

Menurut Muhammad Athiyah Al Abrasyi yang dikutip M. Roqib (2003: $43)^{10}$ menjelaskan dengan ilmu dan pendidikan perbedaan kelas anatara manusia dapat diperkecil dan sebaliknya persamaan dapat diciptakan. Kemiskinan atau darah keturunan tidak menjadi batu penghalang untuk menduduki posisi tinggi.

\footnotetext{
${ }^{8}$ Helmawati. 2014. Pendidikan Keluarga.Bandung:PT Remaja Rosdakarya, hal. 23

${ }^{9}$ Siti Soemandari dan Myrtha Soeroto. 2011. Kartini Sebuah Biografi Rujukan Pemimpin Teladan. Jakarta: Jakarta Balai Pustaka, hal. 363

${ }^{10}$ Moh. Roqib, Op. Cit, 2003, hal, 363
} 
Menurut Murthada Muthahari yang dikutip Nirman $(2015: 89)^{11}$ perempuan perlu mendapatkan pendidikan agar menjadi muslimah sejati. Pendidikan yang khusus bagi perempuan yakni pendidikan fisik, intelektual dan moral.

Sedangkan menurut Qasim Amin yang dikutip Eti Nurhayati (2012:146) ${ }^{12}$ pendidikan yang berasaskan upaya mencerdaskan bangsa adalah pendidikan yang memberikan hak yang adilkepada laki - laki dan perempuan dalam memperoleh pendidikan (yang bermutu).

Pendidikan adalah hak semua manusia, baik laki-laki maupun perempuan. Menurut Rasyid Ridha para ulama sepakat bahwa dalam hal memperoleh pendidikan seharusnya diposisikan setara, ketika menuntut ilmu sebagai kewajiban setiap muslim, maka seluruh masyarakat dengan strukur sosial dan politiknya harus mengkondisikan agar kewajiban tersebut bisa dilaksanakan dengan sempurna.

Dalam catatan para ilmuan hadits, para perempuanlah yang terlibat aktif dalam pengajaran dan periwayatan hadits. Tercatat hampir seribu dari sahabat perempuanyang menjadi pengajar atau tepatnya perawi hadits . seperti Aisyah bin Abu Bakr, Asma bin Abu Bakr, Hafshah bin Umar bin Khattab ra, Khansa binti Khidam ra, umm Salamah ra, Umm Ayyub ra, Umm Habibah ra dan banyak lagi yang lainnya.

Anehnya jumlah perempuan yang ilmuan semakin sedikit ketika perkembangan ilmu pengetahuan semakin maju, pada abad ketiga islam misalnya hanya sepuluh perempuan yang dikenal sebagai penyempai pengetahuan. Hal ini mengindikasikan ada hal lain yang menyebabkan kemunduran tersebut.

Persoalan kemunduran pendidikan kaum perempuan bukan pada ajaran islam, bukan juga pada teks-teks hadits, tetapi pada umat islam itu sendiri, yang semakin hari semakin memposisikan perempuan pada tempat marjinal dalam hal pengajaran dan pendidikan. Memperjuangkan pendidikan perempuan adalah meletakkan persoalan pada posisi semula dimana islam awal meletakkannya. Ada anggapan bahwa mendidik seorang perempuan lebih hebat dbandingkan laki-laki.

\footnotetext{
11 Nirman. 2015. Pendidikan Perempuan Menurut Murtadha Muthahari. UIN Sunan Kalijaga Yogyakarta., hal. 89

12 Eti Nurhayati, Op. Cit, 2012, hal. 146
} 
Karena perempuanlah pertama dan awal mendidik terhadap bayi yang dikandung, dilahirkan dan disusui. Pendengaran pertama yang diterima bayi dari sang ibu dan dia adalah perempuan. (Zaitunah Subhan, 2008:399) ${ }^{13}$

Menurut Subhan yang menjadi persoalan adalah umat islam sendiri. Cara pandang dan corak pemikiran yang mendiskriminasi perempuan-perempuan islam sampai hari ini menentukan peradaban pada masa yang akan datang. Persoalan zaman yang semakin kompleks akan menuntut pergeseran pemikiran tersebut karena bagaimanapun seorang perempuan mempunyai peran dan tanggungjawab dalam membangun sebuah peradaban dunia. Seperti yang diungkapkan Nuruddin dalam bukunya.

Dewasa ini persaingan kemajuan terletak pada dunia industri dan teknologi. Sedangkan untuk masuk dalam persaingan masa depan harus menumbuhkan para pemuda dan mendidik mereka dengan pengetahuan yang nantinya dapat dipertanggungjawabkan perjuangan peradaban. Dr.Alexis Carrel mengatakan bahwa seharusnya dimasukkan ke dalam pendidikan anak-anak perempuan, hal-hal yang berkaitan dengan pernikahan danperceraian sebelum pengetahuan-pengetahuan yang lainnya. Selanjutnya perempuan harus bersekolah yang tinggi, karena bagaimana aka nada dokter yang memahami perempuan secara khusus dan ketentuan syariat yang benar jika tidak ada dokter perempuan sekarang ini (Nuruddin, 2004:24). ${ }^{14}$

Belakangan ini diketahui bahwa dapat sukses dalam kehidupan, tidak hanya membutuh potensi otak kiri saja yang merupakan kecerdasan intelektual (Intelektual Quationt), tetapi membutuhkan kecerdasan emosi (Emotional Quationt), bahkan juga kecerdasan spiritual (Spiritual Quationt). Berdasarkan keseimbangan struktur belahan otak, perempuan sangat mungkin mencapai kesuksesan dibanding laki- laki, karena memiliki struktur otak yang relative seimbang.

Berdasarkan hasil penelitian menyimpulkan, umunya perempuan sejak kecil hingga dewasa menunjukkan kemampuan verbal yang baik. Anak perempuan biasanya mulai berbicara lebih awal, cenderung

\footnotetext{
${ }^{13}$ Zaitunah Subhan, Op. Cit, 2008, hal. 399

${ }^{14}$ Nurrudin.2004.Ada Apa Dengan Wanita.Taslima: Prisma Media. Paramadina, hal. 399
} 
memilikiperbendaharaan kata lebih banyak, memperoleh prestasi tinggi di sekolah, mengerjakan tugas, membaca dan menulis yang lebih baik dari laki laki. Anak laki-laki sejak kecil hingga dewasa memperlihatkan kemampuan spasial yang lebih baik, mengerjakan tugas spasial lebih baik, memiliki kemampuan matematika, geografi dan politik yang lebih maju daripada anak perempuan, meski perbedaan ini sangat tipis (Eti Nurhayati, 2012: 154-155). ${ }^{15}$

Menurut Abdurrahman Wahid yang dikutip oleh M.N. Ibad (2011:47-51) ${ }^{16}$ disebutkan bahwa anggapan perempuan lebih lemah dari laki-laki adalah anggapan dunia islam secara umum selama ini, meskipun dalam kenyataannya menunjukkan sebaliknya. hal ini dikarenakan keluasan pergaulannya, banyak menemukkan dan mengakui tingkat kecerdasan atau keilmuan dari kaum wanita yang sering melebihi kaum laki-laki. Selama hidupnya, ada beberapa orang perempuan yang Gus Dur akui kehebatannya, yakni Ibu, guru bahasa Inggrisnya dan guru bahasa Perancisnya ketika Gus Dur belajar di Baghdad.

\section{Konsep Keadilan dan Kesetaraan Gender}

Gender dalam kamus bahasa Inggris yang berarti “jenis kelamin atau seks". Gender dalam ejaan bahasa Indonesia adalah jender. Sedangkan istilah gender menurut The Contemporary English-Indonesian Dictonary diartikan sebagai "penggolongan menurut jenis kelamin". (Peter Salim, 1996:771). ${ }^{17}$

Di dalam Enclopedia Feminisme dijelaskan bahwa jender adalah kelompok atribut dan perilaku yang dibentuk secara kultural ada pada lakilaki atau perempuan (Muhdirahayu: 2002: 177). ${ }^{18}$

Perlu dipahami terlebih dahulu bahwa seks lebih banyak berkonsentrasi kepada aspek biologis seseorang, meliputi perbedaan komposisi kimia dan hormon dalam tubuh, anatomi fisik, reproduksi dan karakteristik biologis lainnya. Seks atau jenis kelamin adalah perbedaan biologis antara laki-laki dan perempuan. Sedangkan gender lebih berkonsentrasi kepada aspek sosial, budaya, psikologi,

\footnotetext{
${ }^{15}$ Eti Nurhayati, Op. Cit, 2012, hal. 155

${ }^{16}$ M.N Ibad. 2011. Kekuatan Perempuan Dalam Perjuangan Gus Dur dan Gus Miek. Yogyakarta: Pustaka Pesantren, hal. 47-51

${ }^{17}$ Peter Salim. 1996. The Contemporary English-Indonesian Dictionary, Jakarta: Modern English Press. hal. 771

${ }^{18}$ Muhdirahayu. 2002. Dictionary of Feminist Theories, (terj) Jogjakarta: Fajar Pustaka Baru, hal. 177
} 
dan aspek-aspek nonbiologis lainnya. Gender ini digunakan untuk mengidentifikasikan perbedaan laki-laki dan perempuan dari segi sosial budaya. Gender menjelaskan semua atribut, peran dan kegiatan yang terkait dengan "menjadi laki-laki” atau "menjadi perempuan" (Al-Istibsyaroh, $2004: 62){ }^{19}$

Jadi gender dan seks atau jenis kelamin sangat berbeda sekali, karena seks atau jenis kelamin bersifat alamiah, sedangkan gender peran dan fungsinya dibentuk oleh keadaan masyarakat, sosial dan budaya. Munculnya peran laki-laki dan perempuan dapat saling berganti. Dalam arti, perempuan tidak hanya berperan domestik, melainkan juga berperan publik. Laki-laki bukan hanya berperan publik, tetapi juga berperan domestik.

Mansour Faqih (2001: 76) ${ }^{20}$ mendefinisikan gender sebagai sifat yang melekat pada laki- laki dan perempuan sebagai hasil dari konstruksi sosial (social contruction) dan kultural (cultural contruction). Sebagai anggapan perempuan itu lemah lembut, emosional, lemah lembut, keibuan dan laki- laki dianggap rasional, kuat, jantan dan perkasa adalah ciri - ciri atau sifat yang dianggap tidak permanen bisa dipertukarkan atau sifat -sifat tersebut bisa jadi berada pada laki - laki dan perempuan. Perubahan ciri dari sifat sifat itu dapat terjadi dari waktu ke waktu dan dari tempat ke tempat yang lain.

Kajian gender lebih memperhatikan pada aspek maskulinitas (masculinity) atau feminitas (feminity) seseorang (Waryono dan Isnanto,2004: 8). ${ }^{21}$ Peran gender tidak berdiri sendiri melainkan terkait dengan identitas dan berbagai karakteristik yang diasumsikan masyarakat kepada laki-laki dan perempuan sebab terjadinya ketimpangan status antara laki-laki dan perempuan lebih dari sekedar perbedaan fisik biologis tetapi segenap nilai sosial budaya yang hidup dalam masyarakat turut memberikan andil.

Perbedaan jenis kelamin melahirkan perbedaan gender dan perbedaan gender telah melahirkan berbagai ketidakadilan. Faktor yang menyebabkan ketidakadilan gender adalah akibat adanya gender yang dikonstruksikan secara

${ }^{19}$ Al-Istibsyaroh.2004. Hak-Hak Perempuan Relasi Gender Menurut Tafsir Al-Sya'rawi, Jakarta: Teraju. Hal. 62

${ }^{20}$ Mansour Fakih. 2001. Analisis Gender dan Transformasi Sosial, Jogjakarta: Pustaka Pelajar, hal. 62

${ }^{21}$ Waryono Abdul G. dan Muh. Isnanto. 2004. Isu-Isu Gender dalam Kurikulum Pendidikan Dasar dan Menengah, Jogjakarta: IISEP, hal. 8 
sosial dan budaya. Ketidakadilan tersebut dikarenakan tidak terpenuhinya hak-hak dasar manusia bagi perempuan atau laki-laki. Hak yang dimaksud adalah hak untuk menentukan diri sendiri secara mandiri.

Pengertian jenis kelamin merupakan penafsi ran atau pembagian dua jenis kelamin manusia yang ditentukan secara biologis dengan (alat) tanda-tanda tertentu pula, bersifat universal dan permanen, tidak dapat dipertukarkan, dan dapat dikenali semenjak manusia lahir. Itulah yang disebut dengan ketentuan tuhan atau kodrat. Dari sini melahirkan istilah identitas jenis kelamin (Mufidah, $2008: 3) .^{22}$

Dengan demikian dapat disimpulkan bahwa, jenis kelamin adalah perbedaan antara laki-laki dan perempuan yang di tentukan oleh perbedaan biologis yang melekat pada keduanya. Jenis kelamin adalah tafsir sosial atas perbedaan biologis laki-laki dan perempuan. Gender adalah pembedaan peran, fungsi dan tanggung jawab anatar perempuan dan laki-laki yang dihasilkan dari konstruksi sosial budaya dan dapat berubah sesuai dengan perkembangan zaman, gender di pahami sebagai jenis kelamin sosial.

Secara umum, pengertian Gender adalah perbedaan yang tampak antara laki-laki dan perempuan apabila dilihat dari nilai dan tingkah laku. Dalam Women Studies Ensiklopedia dijelaskan bahwa Gender adalah suatu konsep kultural, berupaya membuat perbedaan (distinction) dalam hal peran, perilaku, mentalitas, dan karakteristik emosional antara laki-laki dan perempuan yang berkembang dalam masyarakat. Bias-bias gender tersebut adalah :

1. Penekanan pada peran gender tradisional (psikologi berasumsi masalah perempuan akan terselesaikan melalui perkawinan atau dengan menjadi istri yang baik).

2. Bias dalam harapan-harapan atau sikap-sikap yang merendahkan perempuan (menganggap tidak pantas) sikap asertif dan aktualisasi diri perempuan dan menengkan pentingnya ciri-ciri dependensi dan positivitas bagi perempuan yang asertif dan menampilkan dorongan kuat untuk berprestasi sebagai individu yang memiliki penis envy.

\footnotetext{
${ }^{22}$ Mufidah, 2008, Psikologi Keluarga Islam Berwawasan Gender, Malang: Uin Malang Press, hal. 3
} 
Secara langsung maupun tidak langsung mengindikasikan bahwa perempuan adalah obyek seksual laki-laki dan harus menyesuaikan diri dengan peran tersebut laki lebih kearah ketidaktergantungan, pencukupan diri (selfreliance) dan pencapaian. Kemudian muncul pertanyaan apakah ada konsekuensi psikologi dan sosial dari perlakuan dan pengalaman yang berbeda dari anak laki-laki dan perempuan.

Saat lahir bayi sudah memiliki suatu kelamin, tetapi belum memiliki kejenis-kelaminan (gender). Pada saat itu, jenis kelamin biologis seseorang ditetapkan berdasarkan pandangan anatomis fisik, secara budaya ini menj adi akar dari pengalaman, perasaan dan prilaku, karena pengaitan yang dilakukan oleh orang dewasa dengan cara perbedaan biologis kelak memberi kejenis kelaminan pada si bayi, kebanyakan pandangan yang hendak ditinjau adalah dalam konteks apa laki-laki dan perempuan itu berbeda dan dalam apa keduanya sama (Mufidah, $2008: 9) .^{23}$

Kesetaraan berasal dari kata setara (matcahing, equal) berarti sejajar (sama tingginya), sepadan, dan seimbang. Jadi keadilan gender berarti suatu proses dan perlakuan adil terhadap perempuan dan laki-laki. Dengan keadilan gender berarti tidak ada pembakuan peran, beban ganda, subordinasi, marginalisasi, dan kekerasan terhadap perempuan maupun laki-laki. Sedangkan kesetaraan gender adalah kesamaan kondisi bagi laki-laki dan perempuan untuk memperoleh kesampatan serta hak-haknya sebagai manusia.

Keadilan dan kesetaraan gender yaitu terciptanya kesamaan kondisi dan status laki-laki dan perempuan untuk memperoleh kesempatan dan menikmati hak-haknya sebagai manusia agar sama-sama berperan aktif dalam pembangunan. Dengan kata lain, penilaian dari penghargaan yang sama oleh masyarakat terhadap persamaan dan perbedaan laki-laki dan perempuan serta pelbagai peran mereka (Hamdanah, 2005: 249). ${ }^{24}$

Keadilan gender mengantar perempuan dan laki-laki menuju kepada kesetaraan di mana kesamaan kondisi dan status untuk memperoleh kesempatan dan menikmati hak-haknya sebagai manusia agar mampu berperan dan

${ }^{23}$ Ibid, hal. 9

${ }^{24}$ Hamdanah. 2005. Musim Kawin di Musim Kemarau; Studi Atas Pandangan Ulama Perempuan Jember Tentang Hak-Hak. Jogjakarta: BIGRAF Publishing, hal. 249 
berpartisipasi dalam pembangunan, politik, ekonomi, sosial, budaya, pendidikan, pertahanan dan keamanan dalam menikmati hasil pembanguan tersebut.

Ketidakadilan gender yang tersosialisasi kepada kaum laki-laki dan perempuan secara mantap akan mengakibatkan ketidakadilan tersebut merupakan kebiasaan dan akhirnya dipercaya bahwa peran gender itu seolah olah merupakan kodrat dan akhirnya diterima masyarakat secara umum. Hal ini disebabkan karena terdapat kesalahan atau kerancuan makna gender. Karena pada dasarnya gender yang merupakan konstruksi sosial, justru dianggap sebagai kodrat yang berarti ketentuan Tuhan. Misalnya pekerjaan domestik, seperti merawat anak, merawat rumah sangat melekat dengan tugas perempuan, yang akhirnya diangap kodrat. Padahal sebenarnya pekerjaan tersebut adalah konstruksi sosial yang dibentuk, sehingga dapat dipertukarkan atau dapat dilakukan baik laki-laki maupun perempuan.

Faktor-faktor yang melanggengkan ketidakadilan gender menurut Mansour Fakih (2001:21) ${ }^{25}$ adalah (1) Budaya patriarki, (2) Sistem ekonomi, (3) Sistem, (4) kepercayaan/ penafsiran agama/agama, (5) Adat sosial, (6) Sistem politik. (7) Sistem pendidikan.

Sesungguhnya perbedaan gender (gender different) tidaklah menjadi masalah sepanjang tidak melahirkan ketidakadilan gender (gender inequalities) Namun persoalannya tidaklah sesederhana yang dipikirkan, ternyata perbedaan gender tersebut telah melahirkan berbagai ketidakadilan baik laki-laki maupun perempuan. Jadi ketidakadilan gender adalah suatu sistem dan struktur dimana kaum laki-laki dan perempuan menjadi korban dari sistem itu.

Guna memahami bagaimana perbedaan gender telah berakibat pada ketidakadilan gender tersebut dapat dipahami melalui berbagai manifestasi ketidakadilan tersebut diantaranya yaitu:

1. Proses marginalisasi dan pemiskinan terhadap kaum perempuan

2. subordinasi pekerjaan kaum perempuan

3. Stereotip atas pekerjaan perempuan

4. Beban kerja lebih berat.

${ }^{25}$ Mansour Faqih, Op. Cit, 2001, hal. 21 
5. Kekerasan (Modul Pelatihan KKG, 2009: 41-42) ${ }^{26}$

Perempuan, bukan menerima saja kenyataan hidup. Kesalahan utama yang dilakukan para politisi dan peneliti adalah mereproduksi struktur patriarki dengan menekankan wacana ketimpangan gender, perempuan sebagai mahluk lemah, tergantung dan halus. Melacak akar persoalan pendidikan berbias gender dimulai di keluarga, dilanjutkan di dunia pendidikan. Proses pembangunan terbukti telah memarginalkan perempuan. Proses marginalisasi ini berasal dari kebijakan pemerintah, keyakinan atau penafsiran ajaran agama, tradisi kebiasaan dan bahkan dari asumsi ilmu pengetahuan. Usaha yang harus dilakukan untuk mencapai kesetaraan gender nampaknya bukan hanya sekedar bersifat individual, namun harus secara bersama dan bersifat institusional, utamanya dari pihak-pihak yang memiliki kewenangan

Peranan pembuat kebijakan dan perencanaan pembangunan menjadi sangat penting dan menentukan arah perubahan menuju kesetaraan gender atau dapat dikatakan bahwa negara atau pemerintah mempunyai peran/ andil dalam mewujudkan keseimbangan Kementrian Negara Pemberdayaan Perempuan Republik Indonesia. Dalam setiap perencanaan pembangunan, gender hendaknya dijadikan sebagai "kata kunci" dalam memahami kegiatan apa yang dilakukan laki-laki dan perempuan, Berapa banyak waktu yang diperlukan untuk kegiatan tersebut, Siapa yang memutuskan, dan sebagainya. Terwujudnya kesetaraan gender dan keadilan gender ditandai dengan tidak adanya diskriminasi antara perempuan dan laki-laki, dengan demikian mereka memiliki akses, kesempatan berpartisipasi, dan kontrol ata pembangunan serta memperoleh manfaat yang setara dan adil.

Memiliki akses dan partisipasi berarti memiliki peluang atau kesempatan untuk menggunakan sumber daya dan memiliki wewenang untuk mengambil keputusan terhadap cara penggunaan dan hasil sumber daya tersebut. Memiliki kontrol berarti memiliki kewenangan penuh untuk mengambil keputusan atas penggunaan dan hasil sumber daya. Sehingga memperoleh manfaat yang sama dari pembangunan. Kebijakan pemerintah tentang gender harus disosialisasikan

\footnotetext{
${ }^{26}$ Modul Pelatihan KKG: Bagi Organisasi Masyarakat Keagamaan. 2009. Jakarta: Deputi Bidang
} Pemberdayaan Lembaga Masyarakat, 2009), hal.41-42. 
pada aspek pembangunan misalkan pendidikan, budaya, ekonomi, politik dan lain-lain.

\section{Pemikiran-Pemikiran Pendidikan Perempuan}

Seperti dalam pembahasan sebelumnya bahwa perempuanpun banyak memiliki jasa dalam kemerdekaan Indonesia. Termasuk juga perjjuangan perempuan dalam pendidikan. Tokoh pemikiran pendidikan Indonesia begitu banyak namun dalam pembahasan ini hanya beberapa tokoh perempuan yang akan dijelaskan, diantaranya Dewi Sartika dan R.A Kartini, Rahmah El Yunisiah dan Rasyid Ridho.

\section{1) Dewi sartika}

Raden Dewi Sartika merupakan pahlawan nasional yang berasal dari Bandung dan telah mengambangkan pendidikan kaum perempuan. tepatnya pada Tahun 1904, telah berdiri sebuah lembaga pendidikan yang khusus diperuntukkan bagi kaum perempuan. sekolah ini bernama Sakola Kautamaan istri, didirikannya sekolah ini karena kondisi kaum perempuan yang seringkali mendapat perlakuan diskriminatif dalam memperoleh pendidikan

Raden Dewi sartika merupakan sosok perempuan yang cerdas, mempunyai keberanian tinggi, tidak menyerah dan ramah terhadap semua orang. Beliau memiliki cita-cita yang besar untuk memajukan pendidikan kaum perempuan khususnya di wilayah Pasundan. Kemudian beliau mewujudkan cita-citanya dengan mendirikan sekolah Kautamaan Istri.

Sekolah Kautamaan istri sekarang ini menjadi Yayasan Raden Dewi Sartika yang memiliki tiga lembaga pendidikan yaitu Taman Kanak-kanak (TK) Dewi Sartika, Sekolah Dasar Swasta (SDS) Dewi Sartika, Sekolah Menengah Pertama Swasta (SMPS) Dewi Sartika. Yayasan Dewi Sartika saat ini diketuai oleh Dr. Hj Yooce Yovrinda Krisnawati. Kontribusi yang diberikan oleh Raden Dewi Sartika kepada rakyat bandung berupa bangunan sekolah. Sedangkan untuk pendidikan perempuan di Indonesia, Raden Dewi Sartika memberikan perjuangan untuk mengangkat derajat kaum perempuan agar dapat memperoleh hak yang 
sama dengan laki-laki dalam mengenyam pendidikan (Siti Soemandari \& Myrtha Soeroto, 2011:341) $)^{27}$

\section{2) RA Kartini}

Zaman terus berkembang. Kemajuan ilmu pengetahuan dan teknologi menempatkan bidang pendidikan sebagai pilar utama pembangunan bangsabangsa didunia barat. Kartini menyadari kenyataan itu diusia belia, saat dia terkungkung dalam sangkar emasnya. Cakrawala pemikiran Kartini terus terfokus pada masalah keterbelakangan pendidikan yang menghambat kemajuan bangsanya. Kartini yakin hanya dengan pendidikan rakyatnya mampu bangkit dari tidurnya selama berabad abad. Itulah kunci bila ingin maju dan terlepas dari kebodohan dan kemiskinan.

"Bagiku pendidikan berarti membentuk watak dan akal pikiran" ucap Kartini kepada salah seorang teman Belandanya. Kartini menghendaki sistem pendidikan yang mngutamakan watak untuk semua disiplin ilmu, terutama yang bermanfaat bagi masyarakat luas, seperti kesehatan, kedokteran, bidan/perawat, apoteker obat tradisional, pamong praja, hokum juga agama.

Gagasan kartini ini ternyata menyerupai penelitian modern. keseimbangan intelektual, emosional dan spiritual dapat membentuk pribadi yang utuh. Jembatan dari ketiganya adalah pendidikan seni budaya yang perlu diajarkan sejak dini. Andai saja gagasan pendidikan ini diajarkan setiap jenjang pendidikan, niscaya terciptalah generasi muda yang berbudi luhur, cinta tanah air, punya harga diri, tangguh dan tidak larut oleh pesona gemerlap modernisasi. (Siti Soemandari \& Myrtha Soeroto, 2011:361) $)^{28}$

\section{3) Al-Qabisi dan Rasyid Ridha}

Al-Qabisi memiliki perhatian yang besar terhadap pendidikan. Menurutnya, bahwa mendidik anak-anak merupakan upaya amat strategis dalam rangka menjaga kelangsungan bangsa dan negara. Oleh karena itu, dalam pandangan Al-Qabisi, pendidikan anak harus dilaksanakan dengan penuh kesunguhan dan ketekunan yang tinggi.

\footnotetext{
27 Siti Soemandari dan Myrtha Soeroto. 2011. Kartini Sebuah Biografi Rujukan Pemimpin Teladan. Jakarta: Jakarta Balai Pustaka, hal. 341

${ }^{28}$ Ibid, hal. 361
} 
Pendapat Al-Qabisi yang menakjubkan tentang perhatiannya di bidang pendidikan antara lain adalah anak-anak yang masuk di Kuttab tidak ada perbedaan derajat atau martabat. Baginya pendidikan adalah hak semua orang tanpa ada pengecualian. Al Qabisi mengehendaki agar penyelenggaraan pendidikan anak-anak muslim dilaksanakan dalam satu tempat, dan memperoleh pengetahuan dari pendidik (guru) yang satu. Perhatian Al- Qabisi terhadap pendidikan anak tersebut bukan saja hanya tertuju pada anak laki-laki, akan tetapi pendidikan bagi anak perempuan menurutnya merupakan suatu keharusan, sama dengan pendidikan anak laki-laki. (Muhammad Munir Mursi, 1987:120). ${ }^{29}$

Sebagaimana Al-Qabisi, Rasyid Ridha dikenal sebagai seorang tokoh pembaharu abad XIX yang produktif memberikan gagasan pemikiran dalam dunia Islam. Arah pembaharuan pemikiran Rasyid Ridha tidak jauh berbeda dengan sang guru, Muhammad Abduh. Ide-ide pembaharuan penting yang dikumandangkan Rasyid Ridha, antara lain, dalam bidang agama, pendidikan, politik dan sebagainya.

Di bidang pendidikan, Rasyid Ridha berpendapat bahwa umat Dalam bidang ini, Rasyid Ridha pun berupaya memajukan ide pengembangan kurikulum dengan muatan ilmu agama dan umum. Selain itu, mengingat pentingnya posisi pendidikan terhadap umat Islam, Rasyid Ridha juga sangat memperhatikan pendidikan perempuan. Secara umum, Rasyid Ridha memandang bahwa pendidikan bagi setiap muslim mutlak adanya. Menurutnya, jika manusia diciptakan sebagai penopang kebahagiaan dan poros bagi kebaikan semua persoalan agama dan dunianya, maka setiap individu dari umat Islam harus berupaya sekuat tenaga mengarahkan kekuatan akal dan maeterinya untuk mendapatkan keutamaan melalui pendidikan. (Muhammad Munir Mursi, $1987: 204)^{30}$

Melalui pendidikan, menurut Rasyid Ridha dimungkinkan terwujud ikatan sosial dan keadilan sosial, terungkap berbagai pengetahuan dan kreasi-kreasi baru yang mangandung manfaat, dan terkuak berbagai kemampuan dan kesiapan individu-individu guna merealisasikan kemajuna, kesatuan, dan persatuan. Selain

\footnotetext{
${ }^{29}$ Muhammad Munir Mursi, 1987, al-Tarbiyah al-Islamiyah Usuluha wa Tatawwuruha fi al-Bilad al-Arabiyah. Cet. IV; Mesir: Dar al-Ma’arif, hal. 120

${ }^{30}$ Ibid, hal. 204
} 
itu, melalui pendidikan pula dimungkinkan memahami agama sebagaimana ulama salaf memahaminya serta meninggalkan kejumudan dan keyakinan-keyakinan menyimpang, sehingga kemuliaan Islam bisa kembali lagi dan kembali menghampiri para pemeluknya.

Berdasarkan pandangan ini memberikan kesimpulan bahwa pendidikan itu harus menjadi sesuatu yang wajib diadakan di setiap tempat, diberikan kepada setiap individu umat, dengan asumsi bahwa pendidikan dan pengajaran merupakan spirit yang menjadi nafas bangsa dan umat. Rasyid Ridha mendasarkan pandangannya tentang pentingnya pendidikan dan pemudahan jalan bagi itu pada dalil-dalil al-Qur'an dan al- Sunnah.

Rasyid Ridha memberikan argumentasi, bahwa ayat-ayat al-Qur'an maupun al-Sunnah banyak berbicara persoalan keimanan, pengetahuan, amal shaleh, ibadah, dan muamalah baik kepada kaum laki-laki maupun kepada kaum perempuan. Allah swt telah memperuntukkan bagi mereka (perempuan) segala sesuatu seperti yang diperuntukkan bagi kaum laki-laki, kecuali sedikit ada perbedaan lantaran perbedaan tabi'at (seperti hamil dan menyusui) dan tugas wanita dipandang dari segi hukum.

Rasyid Ridha maupun al-Qabisi mengakui adanya hak-hak perempuan untuk mengikuti pendidikan. Sehingga dalam perkembangan selanjutnya, pendidikan kaum perempuan sangat diperhatikan oleh Rasyid Ridha dan alQabisi. Rasyid mengatakan sebagaimana dikutip oleh Mappanganro (2008:65) ${ }^{31}$ bahwa terdapat ajakan untuk memberi pendidikan pada perempuan dengan pendidikan yang bebas, sama dengan pria dalam berbagai hal, sehingga mereka tidak ada perbedaan satu sama lain.

Disimpulkan bahwa pada prinsipnya Rasyid Ridha dan al-Qabisi tidak mempermasalahkan pemberian kesempatan yang sama kepada kaum perempuan untuk berkompetisi dalam memperolah ilmu pengetahuan di semua lembaga pendidikan, baik di tingkat formal, informal, maupun non formal.

Rasyid Ridha maupun al-Qabisi memiliki pandangan lain yang berkisar pada pelaksanaan pendidikan di mana di dalamnya terjadi percampuran atau

\footnotetext{
${ }^{31}$ Mappanganro. 2008. Rasyid Ridha dan Pemikirannya tentang Pendidikan Formal. Makassar:
} Alauddin Press, hal. 65 
penggabungan antara laki-laki dan perempuan dalam satu ruangan yang dikenal dengan istilah koedukasi. Percampuran belajar antara peserta didik laki-laki dan perempuan dalam satu tempat yang dikenal dengan coeducational class menurut pandangan Al-Qabisi dan Rasyid Ridha adalah suatu hal yang tidak baik.

Al-Qabisi dan Rasyid Ridha tidak setuju bila murid laki-laki dicampur dengan peserta didik perempuan dalam al-kuttab, sehingga peserta didik tersebut harus belajar sampai usia balig (dewasa). Al-Qabisi sebagaimana halnya Ibnu Sahnun, sependapat bahwa guru yang paling tidak disukai adalah guru yang mengajar anak-anak perempuan remaja, kemudian mereka dicampur dengan anak laki-laki remaja. Hal demikian akan menimbulkan kerusakan terutama bagi anak perempuan remaja.

Salah satu alasan mengapa al-Qabisi berpegang teguh pada pendapatnya itu adalah karena ia khawatir kalau anak-anak itu sendiri menjadi rusak moralnya. Hal yang demikian dalam pandangan Al-Qabisi dapat memperburuk tingkah laku anak-anak. Maka pemisahan tempat pendidikan wajib dilakukan demi terjaga keselamatan anak-anak dari penyimpangan-penyimpangan akhlak.

Al Qabisi memperingatkan agar tidak mencampurkan anak kecil dengan remaja yang telah dewasa kecuali bila anak remaja yang telah balig tidak akan merusak anak kecil (belum dewasa). Selain itu, sikap Al-Qabisi yang tidak sependapat dengan percampuran laki-laki dan perempuan dalam satu tempat dalam belajar itu, antara lain didasarkan pada pandangannya bahwa dorongan syahwat biologis (seksual) termasuk dorongan yang paling kuat, dan jika berdekatan dengan wanita dikahwatirkan akan terjadi pelanggaran seksual yang dapat merendahkan martabatnya dan menjauhkan dari keimanan dan ketakwaan yang ada dalam dirinya.

Sikap Al-Qabisi dalam konteks ini tampak lebih didasarkan pada sikap yang amat hati-hati dalam menjaga moral agama. Di sini terlihat dengan jelas betapa perinsipnya yang demikian kuat berpegang kepada agama dan taat beribadah kepada Allah swt. Al-Qabisi menegaskan, bahwa yang perlu diperhatikan secara serius dalam masyarakat Islam adalah menegakkan kewajiban memisah antara jenis laki-laki dan perempuan, mengajak kepada mereka untuk menghindari dari kedekatan untuk berbuat zina. Pendapat Al-Qabisi di atas, 
tampak kuno dan tidak diterimamasyarakat modern yang menuntut kesamaan derajat dan kemitraan sejajar.

Dalam hubungan ini Al-Qabisi menilai, pendapatnya terkesan kuno, namun pendapat itulah yang sesuai dengan ajaran agama Islam, karena anak yang berusia muharriqah (masa puberitas/remaja) tidak memiliki ketenangan jiwa dan timbul dorongan kuat untuk mempertahankan dan menjaga kehormatannya (jenis kelaminnya) hingga sampai mencapai umur dewasa.( Abuddin Nata, 2001:37). ${ }^{32}$

Konsistensi sikap dan pandangan Al-Qabisi terkait koedukasi ini, tidak terlepas dengan kompetensinya pada bidang fiqh yang berdasarkan pada al-Qur'an dan al-Sunnah. Al-Qabisi menghendaki agar pendidikan dan pengajaran dapat menumbuh kembangkan pribadi anak sesuai dengan nilai-nilai Islam yang benar. Sebagaimana al-Qabisi, alasan penolakan Rasyid Ridha terhadap sistem koedukasi oleh karena, Rasyid Ridha memandang dari dari segi positif dan negatifnya percampuran tersebut.

Rasyid Ridha menolak adanya koedukasi itu dari segi negatifnya, dan tidak memandang adanya segi positif atau manfaat dari sistem koedukasi dalam pendidikan Islam. Alasan-alasan penolakan Rasyid Ridha terhadap sistem koedukasi, paling tidak didasari atas pertimbangan beberapa keburukan. Diantara keburukan koedukasi tersebut menurut Rasyid Ridha adalah sebagai berikut: ${ }^{33}$

Pertama, dengan sistem koedukasi, antara laki-laki dan perempuan berkumpul di sekolah, maka kedua jenis itu akan potensial mengalami kesibukan hati, saling curi pandang, saling berbicara, dan sebagainya. Semua itu dapat mempengaruhi daya nalar terhadap ilmu. Selanjutnya Rasyid Ridha mengemukakan, bahwa dengan saling berdekatan akan mengobarkan perasaan dan hubungan pergaulan yang akan membangkitkan kehangatan, sehingga dapat memicu timbulnya perasaaan dengan kecenderungan untuk menaruh perhatian terhadap lain jenis (baik laki-laki maupun perempuan).

Kedua, dengan saling berdekatan akan mengundang kepada saling mempertukarkan rahasia dan perasaan serta memperpanjang hubungan, sehingga dapat mengundang bergolaknya syahwat seksual. Hal tersebut dapat menjadi

\footnotetext{
32 Abuddin Nata. 2001. Pemikiran Para Tokoh Pendidikan Islam: Kajian Filsafat Pendidikan Islam. Cet. II; Jakarta: PT Raja Grafindo Persada, hal. 37

${ }^{33}$ Mappanganro, Op. Cit, 2008, hal 53
} 
penghalang menuntut ilmu, oleh karena boleh jadi membawa daya percepatan untuk menikah, bahkan dapat melakukan perbuatan zina.

Ketiga, dengan percampuran laki-laki dengan perempuan di sekolah dalam berbagai tingkatan dan umur merupakan permulaan yang dapat mengantarkan pada percampuran dengan segala bentuknya, seperti dansa, berenang, mengadakan perjalanan bersama, saling berkawan dan saling berpasang-pasangan yang dapat mengarahkan pada pelanggaran norma-norma agama maupun masyarakat yang ada. Dan hubungan ini pun dapat berlanjut bukan saja di sekolah, akan tetapi lebih jauh lagi di luar sekolah. Keempat, bahwa percampuran antara laki-laki dan perempuan mertuntuhkan berbagai hukum agama dan tatakramanya. (Mappanganro, 2008:53)

Berdasarkan pada alasan-alasan yang mendasar tidak diterimanya konsep koedukasi oleh Rasyid Ridha di atas, maka hal itu pula menjadi dasar pemikiran Rasyid Ridha agar wanita diberi pendidikan khusus yang terpisah dari laki-laki. Ia juga menekankan bahwa lingkungan utama bagi pendidikan perempuan adalah keluarga. Pendidikan kaum perempuan di setiap lembaga pendidikan harus selaras dengan watak dasar yang telah difitrahkan Allah swt kepadanya.

Pendidikan keagamaan harus menjadi patokan utama dalam mendidik dan mengajar anak-anak perempuan, di samping sisi-sisi lain yang juga diajarkan sehingga nantinya bisa mengurus keluarga dan rumah tangganya dengan baik. Mereka harus diajarkan kecintaan pada keluarga, keramah tamahan, kebersihan, kasih sayang, pemenuhan hak-hak suami, adil dalam membelanjakan harta, dan segala hal yang terkait dengan pengajaran urusan rumah tangga, menjaga anak, ilmu hitung, sejarah, bahasa Arab, sastra, dan geografi.

Pandangan Rasyid Ridha dan Al-Qabisi menggugah dunia pendidikan untuk lebih berhati-hati terhadap penerapan sistem koedukasi dalam pendidikan Islam, yang mesti dipahami secara arif, bijaksana dan kondisional dalam meraih tujuan pendidikan yang ideal pada setiap ruang dan waktu. Utamanya bagi pengelola lembaga pendidikan untuk tetap konsisten menjaga norma-norma Islami dalam penyelenggaraan pendidikan, sehingga dapat eksis melahirkan generasi yang teguh aqidahnya, dalam landasan spiritual (iman dan taqwa), anggun akhlak- 
moralnya, dan luas penguasaan ilmu pengetahuan dan tekologinya, serta terampil dalam mengolah kehidupannya.

\section{4) Rahmah El Yunisiah}

Dilahirkan pada 31 Desember 1900 di Padang Panjang, Sumatera Barat. Ia adalah putri bungsu dari pasangan Syaikh Muhammad Yunus dan Rafi'ah. Ayahnya adalah seorang kadi di Pandai Sikat yang juga ahli ilmu falak. Kakeknya adalah Syaikh Imaduddin, ulama terkenal di Minangkabau sekaligus tokoh tarekat Naqsanbandiyah. (Lina Zakiyah, 2011: 23) ${ }^{34}$

Perempuan, dalam pandangan Rahmah El Yunusiyah, mempunyai peran penting dalam kehidupan. Perempuan adalah pendidik anak yang akan mengendalikan jalur kehidupan mereka selanjutnya. Atas dasar itu, untuk meningkatkan kualitas dan memperbaiki kedudukan perempuan diperlukan pendidikan khusus kaum perempuan yang diajarkan oleh kaum perempuan sendiri. Dalam hal ini perlu adanya upaya untuk meningkatkan kemampuan kaum perempuan, baik di bidang intelektual, kepribadian ataupun keterampilan.

Rahmah El Yunisiah mendirikan sekolah Diniyah Putri pada 1923, agar dapat memperluas misi kaum modernis untuk menyediakan sarana pendidikan bagi kaum perempuan yang akan menyiapkan mereka menjadi warga yang produktif dan muslim yang baik. Rahmah menciptakan wacana baru di Minangkabau, dan meletakkan tradisi baru dalam pendidikan bagi kaum perempuan di kepulauan Indonesia. Diniyah Putri adalah akademi agama pertama bagi putri yang didirikan di Indonesia.

Tujuan akhir Rahmah adalah meningkatkan kedudukan kaum perempuan dalam masyarakat melalui pendidikan modern yang berlandaskan prinsip-prinsip Islam. Rahmah percaya bahwa perbaikan posisi kaum perempuan dalam masyarakat tidak dapat diserahkan kepada pihak lain, hal ini harus dilakukan oleh kaum perempuan sendiri. Melalui lembaga seperti itu, Rahmah berharap bahwa perempuan bisa maju, sehingga pandangan lama yang mensubordinasikan peran perempuan lambat laun akan hilang dan akhirnya kaum perempuan pun akan menemukan kepribadiannya secara utuh dan mandiri dalam mengemban tugasnya

34 Lina Zakiyah. 2011. Konsep pendidikan perempuan menurut Dewi Sartika. UIN Syarif Hidayatullah fakultas Ilmu Pendidikan dan Keguruan, hal 23 
sejalan dengan petunjuk agama. Selain sebagai pendidik, Rahmah juga merupakan seorang pejuang.

Rahmah adalah orang pertama yang mengibarkan bendera merah putih di sekolahnya setelah mendengar berita proklamasi kemerdekaan Indonesia. Dibawah kepemimpinan Rahmah, Diniyah Putri berkembang pesat. Keberhasilan lembaga ini mendapat perhatian dan pujian dari berbagai tokoh pendidikan, pemimpin nasional, politikus, dan tokoh agama, baik dari dalam maupun luar negeri. Untuk itu pada tahun 1957 Rahmah memperoleh gelar Syaikhah dari Senat Guru Besar Universitas Al-Azhar, Mesir (Zakiyah, 2011: 41). ${ }^{35}$

\section{E. Kesimpulan}

Dilematis tentang pendidikan perampuan. Sebagai bagian dari masyarakat yang diakui secara legal kewarganegaraannya, perempuan memiliki hak yang sama seperti warga negara lainnya, yakni mendapatkan pendidikan yang layak dan berkesinambungan. Hal ini tercermin dari beberapa Undang-undang Republik Indonesia dan beberapa Undang-undang Internasional yang sangat peduli pada hak-hak kaum perempuan, khususnya dalam bidang pendidikan. Pasal 49 Undangundang No 35 Tahun 2014 tentang perubahan atas Undang-undang No.23Tahun 2002 tentang Perlindungan Anak bahwa Negara, pemerintahan, pemerintah daerah, keluarga, dan orang tua wajib memberikan kesempatan yang seluasluasnya kepada anak untuk memperoleh pendidikan.

Aturan dalam pasal tersebut sudah sangat jelas bahwa setiap orang berhak mendapatkan pendidikan. Semua orang berhak memanfaatkan ilmu pengetahuan dan teknologi dalam rangka meningkatkan kehidupan sosial yang lebih baik. Pemerintah harus melaksanakan isi ketentuan dalam pasal tersebut atas dasar nondiskriminasi. Selain itu dapat diketahui pula bahwa ada kewajiban dari pihakpihak yang disebut diatas untuk memberikan hak pendidikan kepada anak. Anak berhak mendapatkan kebebasan dalam memperoleh pendidikan. Pengekangan terhadap anak dalam rangka pemenuhan hak pendidikan merupakan bentuk pelanggaran hak asasi anak.

Realitanya, perjuangan perempuan untuk memperoleh keadilan dalam pendidikan, khususnya di Indonesia hingga saat ini masih terus menghadapi

${ }^{35}$ Ibid, hal. 41 
kendala. Akan ada beberapa faktor selama alur hidup seorang perempuan yang mempengaruhi perkembangan semangat dalam memperoleh pendidikan. Diantaranya, Sampai saat ini masih ada masyarakat yang berkeyakinan bahwa perempuan hanya akan berperan dalam ruang domestik saja yakni rumah tangganya kelak, yang kemudian hanya dipandang sebagai makhluk pelengkap saja. Sehingga meminggirkan perempuan untuk memperoleh pendidikan.

Salah satu bentuk ketidakadilan untuk kaum perempuan adalah anggapan bahwa perempuan itu tidak penting, melainkan sekedar pelengkap dari kepentingan laki-laki, atau dikenal dengan istilah subordination. Dari pemahaman tersebut akhirnya perempuan dikonstruksikan agar tidak perlu sekolah tinggitinggi karena pada akhirmya akan kembali ke dapur juga. Bentuk ketidakadilan lain yakni pelabelan negatif yang dilekatkan kepada perempuan dikenal dengan istilah stereotype. Misalnya, perempuan yang melanjutkan sekolah hingga perguruan tinggi akan melakukan banyak kegiatan-kegiatan yang kurang bermanfaat untuk rumah tangganya kelak, apalagi ketika pendidikannya tinggi hampir seluruh laki-laki akan minder dan perempuan tersebut terancam menjadi perawan tua.

Masyarakat juga masing ada yang berkeyakinan bahwa perempuan dengan fisik yang lebih lemah dan pasif, tidak memungkinkan mereka untuk dapat memenuhi mobilitas/aktvitas sebanyak dan sekuat laki-laki. Masyarakat berasumsi bahwa pendidikan hanya dapat dicapai oleh orang-orang yang mau bergerak dengan mobilitas tinggi, yang mau menghabiskan waktunya untuk membaca buku, melakukan eksperimen berjam-jam di laboratorium, meneliti di lapangan, menulis dan berdiskusi dalam sisa waktunya, dan jika ini dilakukan oleh perempuan akan mengakibatkan mereka kehilangan identitas kewanitaannya karena tidak memiliki waktu untuk melakukan tugas-tugas kewanitaannya dirumah tangga dan keluarganya. Selain itu, fisik perempuan yang lemah yang digunakan untuk mobilitas pendidikan seperti laki-laki akan mengakibatkan perubahan fisik yang tidak menarik lagi bagi kaum laki-laki, dan ini merupakan penyimpangan bagi citra perempuan.

Perempuan, bukan menerima saja kenyataan hidup. Kesalahan utama yang dilakukan para politisi dan peneliti adalah mereproduksi struktur patriarki dengan 
menekankan wacana ketimpangan gender, perempuan sebagai mahluk lemah, tergantung dan halus. Melacak akar persoalan pendidikan berbias gender dimulai di keluarga, dilanjutkan di dunia pendidikan. Proses pembangunan terbukti telah memarginalkan perempuan. Proses marginalisasi ini berasal dari kebijakan pemerintah, keyakinan atau penafsiran ajaran agama, tradisi kebiasaan dan bahkan dari asumsi ilmu pengetahuan. Usaha yang harus dilakukan untuk mencapai kesetaraan gender nampaknya bukan hanya sekedar bersifat individual, namun harus secara bersama dan bersifat institusional, utamanya dari pihak-pihak yang memiliki kewenangan.

\section{DAFTAR PUSTAKA}

Abuddin Nata. 2001. Pemikiran Para Tokoh Pendidikan Islam: Kajian Filsafat Pendidikan Islam. Cet. II; Jakarta: PT Raja Grafindo Persada

Al-Istibsyaroh. 2004. Hak-Hak Perempuan Relasi Gender Menurut Tafsir AlSya'rawi, Jakarta: Teraju.

Ali al-Jumbulati dan Abdul Futuh al-Tunisiy. , Dirasatun Muqaranah fi alTarbiyah al-Islamiya. Diterjemahkan oleh H.M. Arifin.2002, Perbandingan Pendidikan Islam. Cet. II; Jakarta: Rieneka Cipta

Eti Nurhayati. 2012. Psikologi Perempuan. Yogyakarta: Pustaka Pelajar

Hamdanah. 2005. Musim Kawin di Musim Kemarau; Studi Atas Pandangan Ulama Perempuan Jember Tentang Hak-Hak. Jogjakarta: BIGRAF Publishing

Helmawati. 2014. Pendidikan Keluarga.Bandung:PT Remaja Rosdakarya

John M. Echols dan Hassan Syadily,1983, Kamus Inggris Indonesia, Cet XII, Jakarta: Gramedia 
Lina Zakiyah.2011.Konsep pendidikan perempuan menurut Dewi Sartika.UIN Syarif Hidayatullah fakultas Ilmu Pendidikan dan Keguruan.

Mufidah, 2008, Psikologi Keluarga Islam Berwawasan Gender, Malang: Uin Malang Press.

M.N Ibad. 2011. Kekuatan Perempuan Dalam Perjuangan Gus Dur dan Gus Miek. Yogyakarta: Pustaka Pesantren

Mansour Fakih. 2001. Runtuhnya Teori Pembangunan dan Globalisasi. Yogyakarta: Insist

2001. Analisis Gender dan Transformasi Sosial, Jogjakarta: Pustaka Pelajar.

Mappanganro. 2008. Rasyid Ridha dan Pemikirannya tentang Pendidikan Formal. Makassar: Alauddin Press.

Modul Pelatihan KKG Bagi Organisasi Masyarakat Keagamaan. 2009. Jakarta: Deputi Bidang Pemberdayaan Lembaga Masyarakat, 2009), hal.41-42.

Moh Roqib. 2003. Pendidikan perempuan. Yogyakarta: Gama media.

Muhdirahayu. 2002. Dictionary of Feminist Theories, (terj), Jogjakarta: Fajar Pustaka Baru

Muhammad Munir Mursi. 1987, al-Tarbiyah al-Islamiyah Usuluha wa Tatawwuruha fi al-Bilad al-Arabiya. Cet. IV; Mesir: Dar al-Ma'arif,

Musdah Mulia. 2011. Muslimah Sejati. Bandung: Marja

Nirman. 2015.Pendidikan Perempuan Menurut Murtadha Muthahari. UIN Sunan Kalijaga Yogyakarta.

Nurrudin.2004.Ada Apa Dengan Wanita.Taslima: Prisma Media. Paramadina

Peter Salim.1996. The Contemporary English-Indonesian Dictionary, Jakarta: Modern English Press.

Random House. 2001. Webster College Dictionary. New York Toronto London Sydney Auckland.

Redja Mudyaharjo. 2013. Pengantar Pendidikan. Jakarta: Rajawali Press

Siti Soemandari dan Myrtha Soeroto. 2011. Kartini Sebuah Biografi Rujukan Pemimpin Teladan. Jakarta: Jakarta Balai Pustaka.

Waryono Abdul G. dan Muh. Isnanto. 2004. Isu-Isu Gender dalam Kurikulum Pendidikan Dasar dan Menengah, Jogjakarta: IISEP

Yana Suryana. 2015. Gender dalam pendidikan. Yogyakarta : Cahaya Atma Pustaka

Zaitunah Subhan.2008. Menggagas Fiqih Pemberdayaan Perempuan. Jakarta: El Kahfi 